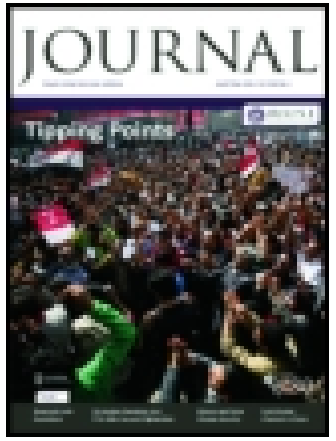

Royal United Services Institution. Journal

\title{
Discussion on the Most Pressing Requirements of the Territorial Force, with Special Reference to Recruiting
}

Colonel The Rt. Hon. Earl Fortescue K.C.B., A.D.C.

To cite this article: Colonel The Rt. Hon. Earl Fortescue K.C.B., A.D.C. (1912) Discussion on the Most Pressing Requirements of the Territorial Force, with Special Reference to Recruiting, Royal United Services Institution. Journal, 56:408, 209-238, DOI: 10.1080/03071841209418182

To link to this article: http://dx.doi.org/10.1080/03071841209418182

曲 Published online: 11 Sep 2009.

Submit your article to this journal $\pi$

山 Article views: 5

Q View related articles $\longleftarrow$ 


\section{THE MOST PRESSING REQUIREMENTS OF THE TERRITORIAL FORCE, WITH SPECIAL REFERENCE TO RECRUITING.}

Wednesday, inth January, igra.

Colonel The Rt. Hon. Earl Fortescue, k.c.b., A.D.c., ... in the Chair.

THE CHAIRMAN: I do not mean to detain you, gentlemen, for more than a minute or two because the list of speakers is a long one, and we shall need every moment we can spare to get through in reasonable time. The discussion to-day has been approved by the Secretary of State for War, who has written to express his regret that he cannot be present, but I understand that either the Director of the Territorial Force or a representative of his Department is present. Now, our subject as you are auare is " THE MOST PRESSING REQLIREMENTS OF THE TERRITORIAI. FORCE, Particularly as REgards Recruiting." For the purposes of this debate, therefore, it may be assumed that we are dealing with a system based on voluntary enlistment, and accordingly arguments as to the merits or otherwise of compulsory service will not be in order, and I ask gentlemen kindly to keep them for another day. The only other thing I want to do is to beg speakers to furnish the Secretary with their addresses in order that proof copies of their speeches may be sent to them for correction before they are printed. With this short preface I shall call on Colonel Johnson to address you.

Lieutenant-colonel R. A. Johnson (gth (Cyclist) Battalion, Hants Regiment): Lord Fortescue, my lords, and gentlemen, I have been asked as a member of the Council of the National Defence Association, an Association which is very largely interested in promoting the interests of the Territorial Force, to open this debate with an introduction on very general lines. Speaking to an expert audience like this, every one of whom knows the ropes, it is quite unnecesary for me to make a long speech, and the more so because a number of high authorities are to follow me. I therefore propose to give you the very briefest resume of the detailed points that we shall probably raise to-night, roughly stitched together in such a fashion as to show there is a connection between each and making one consistent line of argument of the whole.

Now the most pressing requirements of the Territorial Force seem to me, at the present moment, to be not so much niatters of detail as matters of broad principle. Mere tinkering in matters of detail, however desirable, is not sufficient to go 
to the root of the matter. The really fundamental matter is that the Territorial Force will never become efficient until it has become popular, but it cannot become popular until there is a belief in it, and, as Lord Rosebery reminded us the other day, belief can only be founded on knowledge. Therefore, belief in the necessity of a Second Line Army is one of the things that is most wanted and most wanting at the present moment. It is really unnecessary for me to embroider this statement. Some people, the peace-by-talking-peace people, and the Blue-IVater School, would have no Second Line Army at all. There are other people of very considerable authority who condemn the Territorial Force simply because it is a Second Line Army, and, as a Second Line Army, not able to meet a First Line Army on equal terms at the very outset of a war. As to the functions either of the First or the Second Line Army, the Naval and Military Authorities most unfortunately hold different views, and eren Army headquarters themselves are not at one upon this important general principle. No wonder if the general public are like sheep without a shepherd! The second want is, therefore, a consequential one, namely, determination on the part of the country as a whole to sink minor differences and personal quarrels in backing that belief. How often have I been told, particularly by intending officers, "No, I will not join you because I want to see"-and then follows from each one some scheme of his own which he thinks is better, but has never yet been approved by practical statesmen as a workable proposition. In the third place what is wanting is equal determination on the part of the Government and-of course it follows-on the part of the military authorities, to back that belief by their administra. tive action. I will illustrate what I mean precisely as to this, later on in my remarks.

The three greatest evils of the present time so far as the prospects of the Territorial Force are concerned are these : First, there is the exaggerated pessimism of the Press. I do not say that some reasonable criticism is not useful-I am going indeed very shortly to indulge in criticism myself - but the things that we are told about the Territorial Force in many papers are wholly unjust and untrue. The second greatest evil is the soothing syrup which is administered by the Secretary of State for Var. Now I am very anxious that I should not be misunderstood in what I mean as to this. I am far from cavilling with Lord Haldane for his optimism. Optimism in my opinion is a fine quality, and for his optimism and his absolutely tireless and heroic endeavours to explain his scheme to the country, the Secretary of State for. War deserves the support, and the enthusiastic support, of every patriotic man. I have often seen the Secretary of State for War blamed for his optimism. If it were not for his optimism and his enthusiastic labours (Edinburgh, Glasgow, Ayrshire, Leicester and Fulham within the compass of a single week) the Territorial Force would have been sneered away by its critics long ago. I do think, 
however, that he has a habit of exaggerating both the numbers which are available at the present moment, and the extent to which our preparations for war have really gone; and this soothing syrup, to members at least of his party, is a stimulus to them, if you can have a stimulating effect from a soothing syrup, to sleep quietly in their beds. For instance, Lord Haldane is constantly telling us that everything has been carefully thought out by the best brains in the Army, the Navy, and the State. That no doubt is perfectly true, but what we want to know is whether those thoughts have really been translated into practice, especially in the provision of war materiel. Is there not, in fact, a good deal of make believe about, not the men or the officers, but the materiel and the organization of this Territorial Force? Of course, those here present, all of whom are connected in some way or another with the Territorial Force, know perfectly well that there is a very great deal of make believe. So does the country, and it is this exaggerated pretence that everything is ready to the last gaiter button, that gives such a handle to the enemies of Lord Haldane's scheme. The third evil is the marked and even ominous silence of Lord Haldane's colleagues in the Cabinet, including even the Prime Minister himself, the chairman of the Imperial Defence Committee, and His Majesty's principal adviser in the great issue of Peace or War. Is the Cabinet with us or against us in our endeavours to make a success of the Territorial Force? Gentlemen, I think, considering how severe our labours are, that we have a right to know.

With regard to the actual situation as regards numbers, I am not going to quote you statistics and figures, because you have them -all at your fingers' ends, but I think it is pretty clear as regards numbers that our real difficulty is not so much anxiety in regard to the popular arms as with regard to the Infantry. There is no doubt the Yeomanry, which is a popular arm, is full up, and the Artillery, which is also a very popular arm, in spite of the criticisms levelled against it, is also full up, and the Army Service Corps and the Army Medical Corps are all wearing smart uniforms, and are drawn from a better class of men, and are doing well. But in some districts, particularly in the large cities, and in my own county of Hampshire, there is a very serious difficulty in getting the required numbers for the Infantry. There is also a decline, which the Secretary of State for War has himself animadverted upon, in the number of :officers. That in itself is a very serious thing, because as the Dowager Empress of China remarked : "You cannot improvise officers." Next I should like to say that, in my opinion at any rate, we must draw a distinction in our criticism about numbers between the numbers actually available for war to-day and the numbers enrolled in the Territorial Force. The situation ought to be very much better on a declaration of war to-day than the actual enrolments in the Territorial Force would appear to justify, 
owing to the recent formation of that most valuable body-the best work that has been done in my opinion during the past year and a half--the National Reserve. I say "ought to be," and not " is," because the National Reserve is at the present moment in an inchoate condition. It is useless to talk about the reserves that would be available to bring the Territorial Force up to full strength on mobilization if the men of the National Reserve are not armed and uniformed and equipped, and not only so, but definitely affiliated to the units to which they would be called up on mobilization. No doubt it takes time to create a new military force, but here, at any rate, in this matter of organizing and arming the able-bodied sections of the National Reserve is a direction in which, having regard to the very serious foreign situation, more expedition is very desirable. On the other hand, I think the National Reserve in itself adds somewhat to our difficulties in getting recruits. After all, the National Reserve, quite rightly, have received a great deal of attention lately; they have had a great many dinners given to them, and they have been well patted on the back. The National Reserve is not confined to really trained soldiers or war veterans who deserve thoroughly well of their country; but is composed of all kinds of people who have served somehow or somewhere within certain very easy limits, and who are entitled to wear a decoration on their coat, to appear at the Lord Lieutenant's dinner, and tell each other after dinner what fine fellows they are. They have heaps of kudos and no obligations whatever, and, of course, in that way they to a certain extent rob the young men who are coming forward and actually doing the work of preparing themselves for the defence of their country of that praise, particularly from the women and the press, which is the only really appreciable return we can make for their unselfish and patriotic service of the State. I wish all good will to the National Reserve in every possible way, but I do say it is a counter attraction and distraction to those of us who are trying to get recruits for the Territorial Force.

The Under Secretary of State for War said the other day : "Of course we have not got the numbers we require, but at any rate, we have smaller numbers and more efficiency." That is a very fine phrase, but in my humble opinion smaller numbers and more efficiency in the case of a voluntarily enlisted force like the Territorial. Force are a contradiction in terms, for the simple reason that it is quite impossible for a company or battalion commander to have good parades, unless he has good numbers, and if he has small parades, he cannot teach men and officers as they should be taught, and if that cannot be done, the efficiency' suffers. Therefore large numbers and more efficiency go together. Snall numbers are not only a deterrent to efficiency; but also a deterrent to recruiting, as obviously people are not going to join a battalion that is all head and no tail as it marches through the streets.

Passing away now from general considerations to 
particulars there are, in my opinion, some actual defects in War Office administration which accentuate the diffculties as regards numbers. I would mention three especially. In the first place there is the system of inelastic peace establishments. This arises from the original plan under which the General Staff distributed the Territorial Force amongst the various districts and areas of population. The cardinal error they made in this distribution is that they took war establishments, when they ought to have taken peace establishments. This has resulted in many districts in men who are available being actually refused because the establishment has already been exceeded. On the other hand it has not, of course, produced any remedy for the case of backward or unwarlike districts that fall below their quota. There I take issue with the General Staff. I would ask them to remember that, given a full peace establishment, a war establishment requiring lower numbers will take care of itself. Let their war establishments be . what they choose, but for his peace establishment let every battalion commander take every possible man he can get and train him to the best of his ability, and then when war comes we can make a selection for colour service and leave the remainder at the depôts as drafts to supply casualties. The next administrative defect is the inelastic nature of the recruiting regulations. It is familiar to all of you, that the Territorial Force was inaugurated on the Ist April, but that the normal time when men who wish to leave cease, at any rate to do much active soldiering in the Territorial Force, is October or November. The men wish to go in October and November, but by the terms of their enlistment they are kept on until May and June, the date from which they were originally enlisted. Meanwhile it is impossible for battalion commanders, with the best will in the world, and even though hundreds of men are clamouring at their doors, to recruit up to their requirements for the coming year until the old hands who will never be any more use to them have terminated the full anniversaries of their original engagements. No doubt but that a grudging sort of concession has lately been made by the War Office with regard to a certain percentage who can be enlisted over and above the establishment during the period in question, but, as I understand from my, brother Commanding Officers, that concession is so niggardly and grudgingly given that it is really of no practical use whatever. A certain proportion may now be enlisted above establishment, but they are on no account to be clothed. That spoils the concession altogether. The inelastic establishments and this absurd deadlock in the winter recruiting contrive, therefore, to produce the ridiculous anomaly that while everybody is going about the country wondering why we cannot get men for the Territorial Force, the commanding officer who wants to enlist men, and has them actually waiting outside, is prevented by the regulations from doing so. Finally, there is the refusal to establish Cyclist companies:- Now here I speak feelingly. I am VOL LVI. 
now endeavouring to raise a Cyclist battalion, and I have no doubt whatever that in Hampshire, although it is a county which has been allotted far more than its proportional share of units to be raised, I shall have no difficulty whatever in getting a full establishment of cyclists. The cyclists are a special and superior class of men, too superior for the infantry, and yet unwilling to learn to ride or drive a horse, and there are plenty of them in my county all willing to come in and bring their bicycles. But why confine the raising of cyclists to a few coastal counties only? And why prevent any battalion of infantry from having more than 13 cyclists-of whom only 2 are allowed any special money grants?: For tactical purposes, not only every battalion of Infantry, but every Regiment of Yeomanry or Brigade of Artillery would be the better for an additional establishment of 100 cyclists, while from the recruiting point of view you would, by a stroke of the pen and at quite a small additional cost, add at least 50,000 men to the Territorial Force.

With regard to the actual situation as regards training, there of course I am not competent to speak. :There are several Divisional Generals here present who can speak on this subject with real knowledge and authority. But I am informed by. General Cowans himself that the standard of training throughout the Territorial Force is a great deal better than a good many people make out. 'The weakness, so far as I have observed, lies rather in the company training, the elementary training, which in its turn affects the advanced training. This weakness has not escaped the attention of high military authorities; and recently both the War Office and the General Officers Commanding have insisted on more elementary work being done in camp. Now this lowering of the standard in camp is no doubt a necessity, but it is a regrettable necessity, because the whole object of getting men into camp is to give them mancuvre training. We want to make the camp training as interesting and as advanced as possible, and from the recruiting point of view the best men will not come for 15 days if during the whole time they have to do repetitions of work they have done during the year. Yet still it is a necessity at the present moment owing to the fact that the company drills are not attended as they used to be in the old volunteer days, and, not being well attended, they are weak and bad and not instructive. Now, coming to remedies; what are the remedies for this state of things? Within the limits of the voluntary system I think there are certain clear remedies. One remedy is that of boy training. If all boys were compulsorily drilled before they reached manhood, there would be no necessity for the dull recruits' drill at company training, which keeps so many trained men away. But, given such advanced company training at the home stations the expensive camp training could then be used for really advanced instruction. In the second place we. want a closer union with the cadet organizations. The War Office and County. Associations are doing all they can to bring that about, but 
they have not succeeded very well so far. I think that the fault lies very much with the leaders of the various cadet organizations themselves, and I blame also my old colleagues the educationalists in this matter. There is a great deal too much parochialism, and, it must be added, sectarianism also, among educationalists and cadet people to please those of us here who really want to see everybody work together. Finally, there is the remedy suggested by Colonel Marshall in the able pamphlet he issued about six months ago, that for company drills it is only just and fair that some payment should be made to the men.

Now that brings me to the money question as it affects the administration. Here we come to the root of things. There is a fundamental defect in our constitutional ideas on this subject.

The other day I was at a-discussion in this room when we were discussing four companies versus eight for the Regular Army, and Mr. Harris, the Assistant Financial Secretary of the War Office; was here. Speaking officially, of course, that gentleman advanced what to $\mathrm{my}$ mind was an astounding proposition. It was to the effect that the problem before the Army. Council was to provide for "a highly elastic expenditure out of a very inelastic income," and that, therefore, any proposals that gave increased efficiency-I am talking of the Regular Army now-couTd only be regarded coldly if they involved additional expenditure. At least, Mr. Harris went on, the advocates of any particular reform which involved increased expenditure must not set their hearts on that reform, as there were so many other ways in which' a given increase might be equally well spent. That was practically saying that we must regard Army Votes as fixed at 27 millions or thereabouts, and that practically no reform, however useful or urgent, had much chance of being accepted, if it led us beyond that figure! Now, I am all for economy, and I daresay there are, as Mr. Harris hinted, some reforms still to be discovered which will give us increased military efficiency for less money; but at the same time to deal with an important question of the kind then under discussion only " coldly" because it involved an additional expense. of E $\mathrm{r} 25,000$ or thereabouts was, in my opinion, to take up a fundamentally wrong-headed attitude.

That, of course, is no doubt the attitude of the Treasury towards Parliamentary votes, and it is an attitude we can only get removed by way of Parliament. The special difficulty that arises from this attitude as it affects the Territorial Force is very plain. Any more money we might obtain for the Territorial Force must be taken away from the Regular Army, and against that, naturally, every sensible person very rightly and properly protests. At the same time I think there is rather a tendency to exaggerate the value of money in this business. After all this Force is founded on the voluntary principle, on patriotism, on the negation of self, and on enthusiasm; and I for one would 
very much deplore it if the money nexus-any monetary advantage to be derived from serving one's country-came to be regarded as the ruling consideration in the Territorial Force. I think probably the proper distinction to draw in deciding all these questions as regards money is to decide which are payments by way of compensation and which are payments by. way of pay. Directly we propose that any officer or man should actually make a profit out of serving his country in the Territorial Force, then I think the thing will become liable to very grave abuse, and we shall have continual agitation for more pay and more pay, and I am not at all certain that we shall not have a strike for a minimum wage. What we must insist upon, however, as necessary requirements I may put as follows. Iirst of all we must have payment of out of pocket expenses in full. That is on the principle of compensation. It is grossly unfair that a man, in addition to giving up his spare time, and a great deal of time that might be actually put to remunerative uses, should have to put his hand: in his pocket, whether for the purposes of attending drill or musketry, or to make good damage to his clothes by handling the greasy rifle on drill nights, and so on. The theory is, of course, that the out of pocket expenses are already paid, but we all know that the theory falls a long way short of the fact. Then, is the differentiation of pay between the various arms wise? Here we have the Infantry in great difficulties for recruits. The popular arms are full of men. And yet sone of the popular arms are paid nearly double what the Infantry are! I am an infantryman myself, and therefore, perhaps, not an impartial witness, but it seems to me rather curious and absurd that we should bring this differentiation of pay between the various arms, which is quite right in the Regular Army, into the Territorial Force. After all, the men, if they are of a superior kind, and if they are not in the Territorial Force by way of hire, but out of patriotism, ought to be willing to receive rather less for wearing a fine uniform and riding a horse than for trudging along on their own legs in a uniform that is nothing like so fine. The infantry; which has to do the dull work and the most important work-for all the other arms exist to help the infantry to win the battle-ought, it would certainly seem, to receive their share in monetary compensation. However, that is an academic question now, unless we are prepared to level the infantry pay up. We could hardly level those of the other units down. Then I come back to what I said originally about the urgent necessity for complete war equipment of the very best, and down to the smallest detail, ready to take the field at a moment's notice. 'It is without the power of the Government, under a voluntary system, to order in recruits-it is without their power to increase the training beyond certain limits-but it is well within their power to say, "However small the number, we will at least make quite certain that these men who give their time voluntarily, shall have every chance, and they shall not he decked out with the outworn equipment and 
outworn guns of the Regular Army." There is no logic whatever in saying that because the Force is not First Line, therefore it should be provided with second-rate materiel. I do not think it is necessary for me to give more than two instances of what I mean. First of all, the Maxim guns of the infantry battalions are an absolute disgrace to anything but the Museum of the United Service Institution; and secondly, there is the absurd fact that the proper military equipment, which every military authority agrees is the proper military equipment, I mean the Mills-Burrowes Equipment, costs more than the Government grant for that equipment, and therefore, as my own County Association told me the other day, we have got either to abandon it for something which is inferior, or cut off some necessary part of it. That, in my opinion, is a matter for the Government and for the War Office to take up, and is their responsibility, and theirs alone. Of course, this kind of treatment has a most depressing effect upon recruiting. If people see they are being treated in this second-rate way they are not going to come in and work hard for what has so much the appearance of being a make-believe show, at least so far as the responsible authorities are concerned. It is like the volunteers of 1804, I think it was, who were only armed with pikes, and when they complained, the War Office wrote endless papers to explain that pikes were a much better form of weapon than muskets.

Then, of course, we want the necessary rifle. ranges and adequate drill hall accommodation, and we want these things quick. What is wrong here is the attitude of the public. As Lord Haldane was complaining the other day; golf stands very largely in the way of the rifle ranges. We have seen in the papers only this week, for instance, that Sheringham, a little Norfolk village, which gains great profit from the prosperity of the country, and especially from the prosperity of the capital city of the country by entertaining seaside visitors, has been protesting against a Territorial camp being held there next summer, and finds every sort of reason-including the alleged insanitary camp arrangements, which is a grave and unjustifiable reflection on the Medical Department-for not allowing the men to come there. Or again there was a correspondence in the Times last spring, which was signed by a lot of learned professors who objected to our going to the New Forest because they wished to preserve the honey buzzard. The only remedy in matters like these is for those who care about this thing to go out into the streets, and to public places, and see whether they cannot bring about a better frame of mind in the public generally. What we have got to do is to preach patriotism and ensure it, and I commend Sheringham ${ }^{1}$ and the professors to the attention of the speakers of the National Service League.

With regard to compensation for loss of time, that involves

1 This grave scandal has now been taken up by MIr. Punch, a gratifying sign of a gradual change in public opinion.-R.A.J. 
very much more difficult questions than compensation for out of pocket expenses. . Obviously, you cannot compensatè a K.C. who is a private in the Artists for the loss of time he spends as a private in that admirable corps, and therefore, when you talk of compensation for loss of time you have to be very wary. There are the separation allowances which all Commanding Officers have urged from the beginning to be just and equitable. They were, as you know, abolished for the married privates when the scheme was first introduced, in spite of the unanimous protests of County Associations and. Commanding Officers; and I understand that the War Office at last are going to make some sort of concession, but that concession, whatever it is, has come too late to prevent soreness about what has been with many men a very great grievance. It will, however, be useful when it does come, and will restore us a part at least of our "lost legions."

Many people in considering the finance problem desire more discretion to be vested in the County Associations in spending. It is in the nature of man, and of woman too, to aspire to a free hand with the purse, especially with somebody else's purse. The principle is sound enough, but it is not much use having a free hand if the money is not there. Shortage of funds is the real reason why there is no freedom of spending. Shortage of funds is the inspiration of pages and pages of the Regulations.

With regard to the money question as it affects the public, there seems to be an impression abroad that because we have been converted from the old Yeomanry and Volunteers into the Territorial Force, therefore the whole rationale of the old thing is destroyed, and private subscriptions are no longer necessary. That attitude of mind is, in my opinion, quite wrong. We are still the Volunteers and Yeomanry under a different name and an improved organization, and I do not understand why the leading people of the County should button up their pockets as they do and refuse to give us the very helpful subscriptions which go so far to promote efficiency, and are a very valuable help to commanding officers when they are in difficulties for some little extra things they wish to do, things which do not come exactly within the regulations or the means of the County Association. Again, we all know that there is any amount of money which might be spent on improving the War Office idea of a drill hall and headquarters. Why in the world should the rich men not help us to provide these very desirable extensions? In the old days the whole building, armoury and all was provided out of private funds. That leads me round to the theory that those who do not serve should at least be made somehow or other to pay. I think that principle might very well be driven home by those of us who are public speakers. No doubt the principle has been already recognized in a very grudging manner by the Chancellor of the Exchequer in his Insurance Act as regards the contribution of the Territorial soldier 
and his employer during camp. As you are all aware, some of us tried to get the employer's contribution remitted for every Territorial during the whole time that he was in the Force, his rights under the Insurance Act remaining. A good fight for this was put up in Parliament by several people interested in the Force, but unfortunately it received no support at all from the Radical Party, and was pooh-poohed by the Chancellor of the Exchequer. However, the principle is established so far as the camp period is concerned, and we have only got to extend that principle. Again, there was an interesting article in National Defence the other day urging that on the principle of "Pay or serve," some sort of a Territorial County rate should be levied. I understand that an actual motion in favour of such a rate was put on the Agenda Paper for the Edinburgh meeting of Council of County Associations last autumn. As a consequence people poured into that meeting; it was, in fact, the largest meeting the Council had ever had. Unfortunately the genius loci was against us; the people only poured in to protest against the very idea of a rate I At any rate; I think they realized the seriousness of the situation, and it is quite true that, unless you can show people in this country that their pockets are in danger, you will never get them to understand anything very seriously except their amusements, their politics, or their religion, and not always all of these.

I have roughly drafted out here a list of detailed questions, but $I$ am not going to read them through as you have them all before you. It seems to me that most of these questions will be probably raised and discussed this afternoon, and if they are, I think they will probably fit in with the general principles and headings which I have just enumerated.

The following are the questions referred to :-

\section{v. SOME SUGGESTED POINTS FOR DETAIIED DISCUSSION.}

1. Is it desirable that the country should get into the habit of regarding army expenditure as bound to be kept under all circumstances below a certain figure?

2. Should there not be a separate rote for the Territorial Force?

3. Is a Territorial rate desirable, to be levied by counties on all persons not serving?

4. Compensation to the man; what form should it take? Separation allowances? Travelling expenses to drillsor actual payment for drills? A day's pay for musketry attendance? Additional pay for camp?

5. Is "bringing in " money a just demand?

6. Is a separate recruiting staff desirable? If so, how should it operate, and under what authority? 
7. Is the War Office idea of a drill hall adequate? If not, should the whole additional expense be borne by the State?

S. What are the difficulties in securing rifle ranges? Are public opinion and private interests sound on this point?

9. Is the personal equipment satisfactory?

10. Are the mobilization equipment and stores in existence?

11. Should the active members of the National Reserve be armed and equipped and definitely affiliated to units?

\section{DISCUSSION.}

The Chairmain: In calling on gentlemen to speak, I am going to be guided by two principles, first the order in which they have made application to speak, and secondly the districts from which they come. $\Lambda$ very great number of gentlemen have sent in their names to the Secretary, and 1 am sure it will be the wish of everybody that we should as far as possible get a representative discussion with speakers from north, south, cast and west.

Colonel H. R. Mends (West Riding of Yorkshire Association), said that if they were going to get the best class of man, a class of man which would average the manhood of the country, the Force would have to be treated a little differently from what it had been so far. At the present moment a man joining the Force got very little encouragement. He knew that in the manufacturing districts the heads of the Labour Party were dead against men joining, and one reason was that they found it difficult enough to keep the men under any sort of discipline to the Unions, and they did not want them to come under any other sort of discipline. They only really got the young fellows, and they hardly touched the better class of artișans.

\section{Encouragement to Mex to Join the Territorials.}

Was that to be wondered at sceing that they got so little encouragement? The men gave their time and they were put to some expense. The pay that they got in camp did not anything like compensatc them, if they lost their wages. It was not every employer who would give wages to the men who went into camp. They also got laughed at by their comrades, and he knew that in many instances it did not do a man any good in his work to belong to the Territorial Force. The Territorial had all that against him and he got no quid pro quo. The Government gave the man no pay for attending his drills; he got very little for attending the camp, and nothing for giving up an afternoon or day to go miles away to a rifle range. He certainly thought that those men who patriotically gave their time to qualify themselves for defending their country, and also entered into an obligation to give their lives if necessary for their country, should have some sort of advantage given them by Government. He would suggest that what was done in the Colonies might be done here, that, up to a certain number of drills, the men should be paid. If a man got 25 . or 25 . 6d. For a maxinum of 20 drills or attendance. at musketry it would be something. 


\section{Differential Treatment.}

But he would go further than that. If the country was going to call on only a certain number of patriotic men to undertake the duty which was the real duty of everyone, then they ought to help those men. They were men who were behaving differently from their fellows, and they ought therefore to receive differential treatment from the Government. Would it not be possible for the Government to make service in one of the Forces the only avenue of approach into the lower ranks of the Civil Service, into the Customs, Excise, Police, Railway Companies, Post Office and so on, so that these positions should only be open to a man who had served his country either in the Navy, Army, or Auxiliary Forces? If such a thing were done they would really get the very pick of the men. Young men would go into the service knowing that, when they finished their soldiering, there was a career open to them. If that were done the force instead of being looked down upon and laughed at, as he was afraid it was now, would be very much looked up to. He thought that was an aspect of the matter that would have to be faced if they were really going to have the men. If they were going to have strict voluntary service they must have such a good class of men that they would be able to stand against any men brought against then, even allhough their opponents had the advantage of much longer training. The only way in which they could equal the training given by universal service to other men was by having a better class of man, and he did not think they coukd get that better class of man in any other way than by the country recognizing that it was its duty to give every encouragement to those men to come forward, or at any rate to give more encouragement than had been given up to the present.

Major:General Sir F. ILloyd, C.Y.O., K.C.B., D.S.O. (Commanding (Velsh Division): I do think it is a great pity that a man who has done excellent service with Yeomanry, actually in the field, should talk about the Territorial Force as a make-believe and a sham. It is certainly far better than anything that has ever gone before. I believe that this pessimism which is running up and down England is doing more harm than anything else in the country. It ${ }^{\circ}$ is all very well to talk about Lord Haldane's optimism, but were it not for optimism where should we be? Would this Territorial Force be anything like what it is? What we want to do is to malie the best of it, not talk about other things.

\section{Recruitisg.}

As to recruiting, we must train all our commanding officers and our company oflicers to recruit. They are the best recruiters. It is no good having recruiting societies inside the regiments, batteries, or battalions, or outside for the matter of that-at least that is my belief. I think if the County Associations who are responsible for recruiting would tell us, and tell our commanding officers, that it is their business to send their captains out into the fields of recruiting, we should do very much better than we are doing now. There are many of them who wish to do it, but they do not get.the impetus. It is a great pity that all divisions are classed together, because almost every division is different in regard to its difficulties of recruiting, in its way of training, and practically: in everything else. In the old days I have had a great deal to do with the Volunteers of London in many ways, and $I$ have the greatest affection and admiration for them and the Territorial Force here, but I would point out that the 
Division which I command is absolutely different from a London Division, and yet I find very many of the things that apply to London applied to the Welshmen.

Training.

With regard to training, it is quite true that company training is a necessity for war, and that the men do not like doing it when they get into the field. My idea is that company training, if possible-and I think it can be done-should be completed before we go out for training. $\Lambda$ s to the money, I do not think that the Finance Department of the Army Council is responsible for the 27 millions of the Army Estimates. If more Estimates are required, I imagine that Parliament will, if necessary, vote them; after that, possibly the Finance Department may have something to do with them. We have to deal with the situation as it is at present, and nothing else. If you take too much money for the Territorial Force, we shall lose in the Regular Army, and the Regular Army is our first line, and the thing that we have first to look after. I do not think at the present moment there is a great shortage of money; we have had a great deal more lately granted to us, and we are doing good work with it. I think we shall get as much as we ought to have as time goes on.

\section{Drill Halls.}

With regard to drill halls, I have just heard that the War Office drill hall is not good enough. The week before last 1 opened three drill halls; I heard no complaint, and I thought they were very much up-to-date. What we really want to do is to make the best of what we can get, and, more than all, put our backs into the work. There is an enormous amount of apathy in the country about defence; nobody thinks it possible that we can be invaded, though of course it is perfectly possible. The more we go about and rub it into people that they must do something for their country, that they must not be apathetic, and that the only thing that we have as far as national home defence is concerned, is the Territorial Force, and that we must do cverything we possibly can for that Force, the better it will be.

Colonel H. A. Raitt (late Commanding S. Midland Division), said that he felt very strongly on the question of the separation allowance. This question was being urged by nearly all the commanding officers and County Associations. Commanding officers told him that if they could get separation allowances for their married men, more men would stay out for the second week in camp. They said that their married men were the best men in the corps, and if they could keep them together, they brought in recruits. He believed all that was perfectly true, but only if they regarded the corps as an easy-groing peace machine. But he did not think they ought to adopt a system that would tend to difficulty and inefficiency in case the Territorial Force were mobilized for permanent training. The separation allowance given to a married private was only, he believed, $1 / 1$ a day, and $1 \frac{1}{2} d$. or $2 d$. for each child up to the age of sixteen or thereabouts. What would the well-paid artisans, the better class of men in the Territorials, do on that allowance in case of mobilization for permanent service? Their wives and families would have to leave their comfortable artisan dwellings, and live in the slums, and that would produce a feeling of intense discontent amongst the miost influential men in the regriment, and he believed it would really lead to the destruction of the spirit of the whole Force. If a separation allowance was granted, they would get a much larger number of married men in the Force, and 
that would make it quite impossible to deal with the question by volun. tary effort in the event of war. During the South African War the married fanilies of the Reservists had to be dealt with by voluntary effort, but this would be quite impossible for a force of 300,000 Tcrritorials. For that reason he, hoped that neither separation allowance nor anything else would be given that would increase the number of marricd men in the ranks. . He thought the idea should be to have the Force a bachelor one. As a married man, he felt bound to say that he thought married men in all armies were a confounded nuisance.

\section{The Club Principle.}

Another thing urgently needed was that the Government should frankly recognize the "Club" principle in the Drill Halls. $\Lambda$ s Col. Mends had said, if they got the men to come in voluntarily to do work that everybody ought to do, they ought to treat them thoroughly well. He did not himself know a single drill hall where what he considered adequate accommodation and recreation for the privates was provided. He knew some where the officers and the sergeants were well provided for, but not a single one with really adequate accommodation. He believed the recognition of that principle and the building of recreation roons would be one of the most potent influences in drawing recruits.

Colonel w. C. Ross (Sutherland, Caithness, Ross and Cromarty, Inverness and Nairn Associations) said that there was one point upon which nobody had touched yet, and which particularly affected the countics in the Far North, which he represented, and that was the question of SergeantInstructors.

\section{Sergeant Instructors in. The Far North.}

The question had been dealt with by the Central Council of County Associations, and by the Army Council, but the result of it all was that at the present moment, so far as they were concerned, all round something like I2,000 square miles of country they had dotted the most discontented representatives of His Majesty's Army that existed on the face of the globe. In the Volunteer period before the Territorial Force was introduced, Instructors had certain allowances, amongst others lodging allowance, which they dren, and the Volunteers to whom the drill halls belonged were good enough to give them their quarters free. That was eventually knocked on the head. When they drew that $f_{18}$, it compensated them in some degree for the dearness of living in those extreme parts, where the cost of living was higher than in any populous district. The result was that they got good men, and men who wanted to stay. But when they lost that allowance and certain other allowances, they were worse off in serving with the Territorials than when they were serving with their own regiments, and accordingly good men did not wish to come, and when they did come they wanted to get away as soon as ever they could. The allowances which they drew, in most cases, in these far Northern Counties, did not cover the cost of the articles which they were supposed to provide. The ration allowance, 6d., was no doubt based on what the Army paid for rations bought in large quantities, but meat and bread in the far North could not be bought at anything like the same price. In the same way they received $2 \mathrm{~d}$. a week for medical attendance, or $8 \mathrm{~s} .8 \mathrm{~d}$. in the year. A marricd man with a family got that rate for each member, but the doctors in those counties did not extend any benefits to the Territorial Instructors, and they charged anything up to $3 \mathrm{~s}$. $6 \mathrm{~d}$. a visit, so that, 
consequently, when a man had a certain amount of sickness in his house he was very greatly out of pocket. He had known of an Instructor who had to pay nearly $£ 20$ in one year for doctor's fees. Their fuel and light allowance was the same. In the far North the normal price of coal was about 275. per ton, without strikes or anything elsel The cost of light was also higher. All over the country prices and conditions varied, and it was impossible to have one code of regulations to cover everything. They had a most excellent arrangement in India, known as the " nerrick" rate, which was fixed or certified by the Government officials in each district. He did not see why that should not be done in this country, and the allowances to Instructors should be proportionate, so as to be in keeping with the rates that obtained in the districts where they were serving. That, it appeared to him, would be the fairest thing to do. He believed that all men with families would prefer to have free medical attendance, which, he understood, they used at one time to get:

There was another matter of some importance. Formerly they had Instructors of colour-sergeant's rank, and they were better off. Now they had sergeant-instructors appointed for two years; he believed in some districts that was considered an advantage. But it was not so in the North of Scotland, because a man required to know his district, and by the time he linew it he was thinking of going away again. $\mathrm{He}$ was not a volunteer; he was ordered to go there by his C.O., who knew he was going to lose money, and was therefore not likely to select his best men to bear the loss. Consequently, they did not get the best. Unless they did have the best they had an extremely bad example for the Army. Not only did they drive away recruits from the Territorial Force, but they also stopped men enlisting in the Regular Army. So far as the Highland Regiments were concerned, he was told this year that, for the first time for some years, the Highland Regiments had been thrown open to recruiting in all parts of the Kingdom, and he believed what he had said had a great deal to do with it. Wherever he went he found an Instructor discontented and unhappy; and naturally men did not want to follow in the same service in which he had, after long service, arrived at such an unsatisfactory end. It must be remembered that in these districts the Territorial Force Instructors were practically the only representatives of His Majesty's Army that the inhabitants ever saw.

There are one or two methods by which he thought they might be helped considerably. There was the system of billeting, for instance, which was most unpopular, and should be abolished. They must remember that in the far North, there was great difficulty as regards officers; that difficulty occurred all over the country, but they in the North were worse off than anyone. In some cases, there were no officers within many miles of the Headquarters of their Company. As an example, in Bonar Bridge in Sutherland, the O.C. Company lived about half a day's journey away, having regard to the poor railway service; one subaltern lived at Wicl: in the far North, and the other lived in Edinburgh. They had to take what they could get, and naturally the whole brunt of the work fell on a cliscontented sergeant-instructor, who was losing money, and who, every time he was sent away from Headquarters, lost more money. Therefore that station did not get much of a chance. This Instructor had three stations, one of which was $5^{6}$ miles away from company headquarters, and in all his moves he had to lose money. Without the personad influence of someone, either the officers, or failing the officers the serfeant-instructor; in that part of the world, they would never be able to kcep up their 
numbers. There must be continual personal influence. Even when they had officers, they were as a rule busy men, who had so much to do to keep alive in these hard times that they really could not afford the time to travel all round their districts to bring their men together. In one company there was a matter of 35 men who did not qualify in 1911 , mainly, he believed, owing to the sergeant-instructor being a discontented man, and not taking the time to go round and see the men; and so the Association lost the whole of the grant, $f_{42}$, for those men. He hoped someone would take this matter up who could speak more strongly on the subject than he could, and with that hope he would conclude.

Major Geueral E. ¿. Bethune (Commanding West Lancashire Division) : I shall confine myself in the ten minutes which are at my disposal to just saying what appears to me to be the first and foremost requisite, and that is the material. We have to get the men, and keep them when we have got them. That applies equally to officers and men. I would like to divide my remarks into two heads, dealing first of all with how to get the soldier and the officer, and, secondly, with how to lieep him when we have got him.

\section{Recruiting for the Territorial Force in Laxcasulre.}

My own experience in West Lancashirc has been a very lucky one. We have Lancashire lads. who are keen and straight and hardy fellows, and who respond very wéll to personal influence, and I have also got Lord Derby, who is Chairman of our Territorial Association, and also Lord Mayor. We have both of us discovered, after going round about Lancashire, anci talking to people, that the greatest difficulty we have to contend with-and I fancy everybody will agree with this-is the absolute apathy and ignorance on military matters of the general public. It is a most impossible thing to get people to understand that such a thing as a Territorial officer could be required at all. They say, "You have the Regular Army-what more do you want?" I always reply, "Bless you, my son, I have to go to India or to the Cape, and it will be you who will have to stop at home and attend to that." One man replied, "That is an extraordinary thing; I have never heard of it before." I said, "Well, you know now." I am always impressing on my friends that we have got to be our own recruiters. Every officer, every man, and every non-commissioned officer, who is a good Territorial, and sets a good example, is a very good recruiter. In Liverpool I have had the most encouraging results. We have got heaps of good men, and as a matter of fact, we do not find much difficulty in getting our fellows. I may say that the Stock Exchange in Liverpool suspended business for ten minutes during the busiest time of the day in order that I might address them. I told them that that was patriotism, and I told them straight what I thought about then. We then went round to the Cotton Exchange, the Corn Exchange, and all the other places, and $I$ find now that we are gradually and slowly beginning to educate the public up to the idea that they have to do something, either give personal service or pay money. It is growing, and $\mathrm{I}$ am perfectly certain that we are going all of us, by putting our backs into the work and working hard, to educate the public, and, if we do that everything we want will follow. The Territorial Force, at least, will follow, provided that we can educate everybody, and put a little enthusiasm into them, and make them feel that it is their duty to defend themselves and look after themselves by producing an Army. The men are willing enough if they 
know anything about it. Our great enemy in the industrial parts of Liverpool is not the people, but the heads of departments or senior clerks who want their holidays in August just at the time when we want to go into camp. These may say to the Territorial men, "All right, my" lad, you want your holidays in August, and so do I-you are no use to us," and they have to shift. The employers know that this goes on, but they do not care to tackle it. When you raise the question they say "Yes, you are a very pleasant fellow, and what you say is all right, but we cannot do impossibilities, and we must leave these men to do what they lilie." I say to them, "You -must let me have the men." The point I wish to malie is that I can get people by simply talking to them in the right light.

It is the same with regard to officers, and in that connection I will tell you what I did last night. I took a place in Liverpool which holds about 5,000 people, and I got every beautiful lady from the pantomime, and stars like George Robey to give us a turn. These people are all very patriotic. I said in my orders that every Territorial soldier who came in uniform, and brought with him two civilians, was to have a free pass, but if he brought nobody with him, he had to pay is. Well, we had 3,500 people to see the show. I can guarantee that they saw a better show than they could see in any hall in London. During the performance I spoke for about ten minutes. I said, "My lads, you have had the .jam, and now you are going to get the powder," and I gave it to them I

\section{Pay or Service.}

Now, as to keeping the fellow's when you have got them, I think every division is different, and every division has its different needs. The main thing, however, is the question of money. The theory of pay or service, I believe to be a very good one. Most of these people say. "Why should I allow my men to go when B and C do not allow their men to go?" and they are tired of it. In fact, employers are getting a little bit sick of doing the job when they find other people are not responding. Good people started and gave us help under the impression that others would follow, but others did not follow, and I belicve we have got to the bottom of the patriotic stratum, and we now have to cducate people, and force them to see the light. I think myself we are getting very near the level where we shall not find very many more men. All the fellows who were willing to come in have practically come in, and they are very good, but there is a limit. We have to keep on educating until we get employers, men, and everybody to see that they have to do something.

With regard to money, I think the system should be not to pay a man. You cannot give him bounties and gratuities. Most of the men I know of in Lancashire say they do not want that, but they want their out of pocket expenses; they do not want to feel that they have to put their hands into their pockets every time they go out. They say, "You can pay us to go to and from the range, and you may give us a sand. wich," and I think that is reasonable. We ought not to go in for paying specialists or giving more money away than we can possibly help, because the more you keep it a voluntary force, and the more you emphasize the fact that it is an honour to serve the country and a shining light and example to other people, the more I think you will get the best class of lads to come in. But the poor fellow on $18 \mathrm{~s}$. or 20s. a week, with a wife and children, I do think should have a separation allowance 
of some sort; I do not think he should be out of pocket, at any rate. He loses his holiday with his wife for one thing. A lot of people will say, "I like to go into camp, you know, but you always pitch the camp in such a wicked part of the country, and my wife cannot come, and I think it is very hard." I always say that everything in this world is hard, but that you have to lump it.

As far as barracks go, I think personally, from what my commanding officers tell me, that old houses that can be adapted are better than a sealed pattern barrack. Every battalion wants a different kind of thing. I find that where we can get an old building and adapt it, cven if it does not come quite up to the War Office scale of $14 \mathrm{ft}$. there, $22 \mathrm{ft}$. here, and so on, there is still heaps of room, and they much enjoy some rambling old house which can be very often obtained for a nominal rent.

\section{Promotion of Officers.}

Of course, we are an abnormal force from the War Office point of view. If a commanding officer is satisfied that a certain officer is qualified, but he cannot attend a course because he is busy in carning his livelihood-he may be a senior partner, and cannot get away-the War Office ought to promote him because he is efficient, and the commanding officer's word must be taken for it. The War Office will have to do a great deal in that way, and I believe they are going to undertake it. We have heard of cases that have been pushed through lately, and I am very glad to see it, because it shows that the War Office is human. The pith of what I want to say is that to get the men we have to use our personal influence. Do not tell them-they are going to get anything out of it, but tell them that their out of pocket expenses will be paid.

I do not know that everybody is ready for mobilization, if you come down to bedrock. I will not say anything about war equipment: I think we are as ready for mobilization as we can be now. I have a battalion with three different kinds of equipment, and that is a serious affair. Of course, all these things are small things if you can only get your man and keep him. Give him any sort of equipment, and the fellow will fight if he has a heart in the right place. My experience of three and a half years in Lancashire is that the Territorials are improving day by day. They are not untrained. I can have a rendezvous during camp in the middle of the night, and they come up within four minutes of time, and if that is not discipline, 1 do not know what is.

The question of rifle ranges brings us up against the horrible golf poople again-although I am a golfer myself. There, again it is a question of education; you must educate the neople to give up some of their golf links to us, and give us a chance. With regard to having a separate vote for the Territorials, I should be inclined to think it would be a good thing, as it would do away with pinching money off the Regulars, which is a matter that frightens the commanding officers. They always say that if certain money is asked for, it will have to be taken off the money that should go to the Regulars, and therefore if we had a separate vote altogether, it would be a great thing for us. As far as the training grant goes, I am perfectly satisfied with the amount of money they give us, but I would like a little more elasticity in the matter of the headings. We might be allowed one column for "Miscellaneous;" into which we could bring a certain expenditure. If a man is fit to command a division of Territorials, he is fit to be entrusted with 6100 without having to 
make him schedule things under different headings which do not fit in with the particular local conditions. The finance people are very hard to get on with, and are, of course, tied by their own rules.

Colonel Sir T. S. Cave, K.C.B.: I should like to say that I am quite sure our greatest difficuity in this matter of recruiting is the disparagement that has been carried on in the press. I have been to recruiting meetings in Surrey and Hampshire within the last few days, and it has been said by the men whose time is to expire shortly, that they could not make up their minds to re-engage because they could not stand the sncers and jeers in the papers.

Strengtil and Establishinent of the Territorials.

With regard to numbers, 1 think that is one of the things that has been falsely stated, and it has created rather a wrong impression in the minds of many people. The Force is by no means very short. It is said again and again that the full establishment of $315,000 \mathrm{men}$ is the minimum which the military authorities consider necessary for the defence of the country. But 315,000 is not the minimum they consider. I do not know what they consider may be necessary for the defence of the country, but I should imagine that the more men we have and the better they are trained the better chance we stand. It is quite impossible to prophesy exactly what number of men are necessary, but 315,000 is the maximum number that the Government will pay for. It is physically impossible to keep any force up to its maximum establishment when the discharges take place at a time of year when it is impossible to fill up the places and to get the necessary preliminary drills done before camp time. In reckoning what the number of the Force can be possibly kept up to, with an establishment of 315,000 , it is necessary to take off ro per cent. straight away. If you do that you will find that the naximum number we really can keep up to, with such an establishment, is only about 270,000 , or 280,000 at the outside, and we are absolutely within about 20,000 of that number.

\section{Re-engagement of Time-expired MeN.}

The difficulty at the present moment is not so much in getting the normal supply of fresh recruits as of inducing the large blocks of men whose time expires either this year or next to re-engage. The great importance of getting these men to re-engage is that we want to get older men in the ranks, and older men out of whom to make N.C.O.'s as time goes on. I remenber that in 1874 the average service of the company of Volunteers which $I$ then commanded was five and half years. Of course, it is impossible with a four years' engagement, unless you get a large number of men to re-engage, to get anything like an average service of five and a half years. If we are really to have fully matured men we must get them to re-engage, and that is really the problem of the present moment, because there are large blocks of time-expired men both this year and next.

\section{Separation Allowaice.}

With regard to the separation allowance, I am sorry to disagree with my late chief, Colonel Raitt, who was my divisional general for four years. 1 have had the advantage of experience in that respect. In ny okd Voluntcer battalion I paid the separation allowance to the married privates for seven years, and I venture to say that at the end of the seven years it would have been very difficult to find a more efficient battalion. 
The men are more fixed to the same locality when they are married, and consequently it is a good thing to get a fair proportion of married men in the ranks. I am delighted to hear that the separation allowance is probably ooming on this year because I am sure it will have a very excellent effect.

I do not think we need at all despair about the numbers we have. We have actually 84 per cent., and as I say, about go per cent. is all you can possibly have. Consequently we are really less than to per cent. below the possibilities.

With regard to recruiting; I am Chairman of a local Recruiting Committee, which is run by the County Association, and I do not think it does one bit of good. I am unable really to help them a bit. The officers, at the present moment, are and always will be the best recruiting agents, and I do not think it is a good plan to keep any sham or pretence going. Consequently I am sure it will be better if it is recognized by the regulations that it rests upon the officers to get recruits, and that they have the responsibility, and the credit for getting the necessary recruits.

If you want 300,000 men the establishments must be raised so as to give the necessary elasticity, and we must be allowed to take the men where we can get them and when we can get them. I have over and over again asked that men, when they have finished their four years' training, may be passed by the C.O. into the Reserve for the rest of their period. It would be a simple process to do that, and a very good one, because you would have a lien on the men in case any emergency should arise, and you could immediately begin to fill their places in the recruiting season, from January to the end of April. I am sorry to say that three circulars which have been issued from the War Office to try and meet my suggestions in that respect, are so hedged round with precautions of the Financial Department, to prevent the possibility of their expending a single farthing upon a man over the establishment, that they are absolutely useless, because they only frighten commanding officers and make them regard it altogether as too dangerous a thing to attempt. If those needless financial precautions n'ere swept away, we should get over one of the great difficulties in recruiting, and it would have the great advantage that you would be able to take the men at any time and make them enicient.

Colonel Sir George T. Beatson (City of Glasgow Association) said that their aim that day should be to devise something that would be not merely a temporary improvement, but which would have a permanently good effect. In this principle of the voluntary system for home defence it seemed to him there were three factors which must always be kept in mind. First of all, there must be a knowledge amongst the people of the dangers that were before them; secondly, they must give them a clear statement as to how those dangers were to be met; and thirdly, whatever means were adopted, they must be carried out in a vay as little oppressive and as little objectionable as possible to those who discharged them. Had those principles been fulfilled in the case of our Territorial Force? He would himself unquestionably say no. There was not before the country a clear and distinct statement as to the dangers that were at present confronting them; and there had not been a clear statement as to how those dangers were to be met. Unfortunately there was a strong division of opinion amongst them upon the latter point. Lord Haldane and his advisers said that 315,000 men were all that were recommended and that those men need not be very thoroughly trained, 
but that real training would begin when war broke out. On the other hand, Lord Roberts said, for the National Service League, that a million of men were required, and that the only way to get the training; was to make it compulsory. Now, with this division of opinion there was no doubt whatever that the nation had become apathetic, and were standing back while the experts were deciding what was to be the size and the nature of our home defence army.

\section{Tile Need for a Definite Defence Policy.}

Thirdly, had the volunteer force, either at its inception or in its administration since, had that considerate, careful, and thoughtflu treatment it should have had?. He said decidedly no, it had not had it. . He could not help saying, and he spoke advisedly, that it was largely the action. of the War Office that had led to the present apathetic condition of the country in connection with the Territorial Force. He believed that the first thing that ought to be done by some responsible body, such as the Committee of Defence, was to make a definite statement and say what actually was the position of things as regards the dangers ahead. He knew, of course, that there must be in diplomacy a certain amount of secrecy, but the nation was entitled to know...what was the policy into which they were drifting and what it was they had to face. Secondly, he thought that the time had now come when they should review the situation and come to some compromise on the question between themselves and the National. Service League. How that was: to : be brought about he was not going into, but he believed that in that direction some suod would come. Lord Haldane had said that his Government would not bring in compulsory service, and he was doubtful if the other party would do it either. IVhile Lord Roberts and the National Service League were waiting for the accomplishment of their hopes the country was suftering and the Territorial Force was being neglected. $\because$ Although he was a strong voluntary man he was strongly in favour of universal military training-not of universal military service. He believed that the training for the Territorial Army should be of such a nature that it should be efficient and that they should not be asked to play at soldiering and then be held up to the disparagement of the public and of military critics. Then he thought that the War Office should change its attitude towards them. This change should take the form, first of all, of giving the County Associations power which they had not at present. The late King had said that not only were the County Associations to raise the forces but that they were to hand them over to the military forces trained and ready to take the field both for camp work and for war. Was that the case? So far they certainly had not had the power to rlo that. That point should be settled. The idea of the Treasury was that the County Associations were there sinuply to relieve the commanding officers of financial responsibility. If that was the case the sooner it was known the better, because he was satisfied that in the City of Glasgow they would not get men' to serve another day if they knew that that was the position. Then he thought there should be a complete change in the financial arrangements of the Territorial Force. The County Associations should have power and should be given a free hand to carry out their duties: Also, sorre steps should be taken' to give commanding officers a little more possibility of coming into touch with their men, so to speak a little more administrative control than they had now. In the old days as a Volunteer C.O. his men knew that, if they had any grievance, it would have full consideration. Now they knew it was not a question 
for the C.O.s, that it had to be transferred to and settled by the War Office. Further, there should be an end to the delay that took place in dealing with the business of the County Associations. There should be a Territorial Force Department separate and distinct. They should also press for greater facilities for training. Employers could not be expected to part with all their men at the same time. In his opinion there should be standing camp. stations in suitable places where men could go at intervals and do their field work or get such a knowledge that they could take the field at once. With those changes and under such new conditions he believed they would find the Territorial Force popular and they would have the ranks filled.

Captain C. J. Wilkie (Glamorganshire Association) said that owing to the fact that they had to raise far less men than would have been possible with their large population, they found less difficulty than other counties seemed to experience. No doubt the sergeant instructor question was a very serious one in the provinces, especially in the small towns and country villages. He agreed that in the past, these men had been pampered too much, but still they could do much to make their lives more comfortable if the War Office would give them the power. For instance, he was told that wherever the War Onice could build a sergcant instructor's quarters connected with a new drill hall at a cost not exceeding $\mathcal{E}_{300}$, they were glad to do it, and yet in his county, where it was very difficult for a sergeant instructor to get satisfactory quarters on anything like his allowance of lodging money, the Association had offered to invest in houses for sergeant instructors, and to give them better quarters in return for their lodging money than they could possibly have obtained even with double their money; but they had not been allowed to because the War Office could not permit Associations to assist these men, either directly or indirectly. Their'protest had, up to the present, been of no avail. As the IVar Office would have had to pay no more, and the men would have got more advantages without any extra pay, it mas difficult to follow the reasoning of the Finance Department.

He had some fear lest the agitation for raising voluntary aid detachments might interfere with recruiting. One of the attractions of the Territorials was that a man liked to be able to walk about in a uniform. In the Voluntary Aid Detachments they got all that, besides afternoon teas, smoking concerts and so on, and he feared that unless the IVar Office limited the number of Voluntary Aid Detachments, difficulties might arise.

His Association had already offered to raise a second cyclist battalion, provided they might have a grant of $\mathrm{f}^{2}$ instead of $30 /-$ for the provision of bicycles. If the cyclist companies, which were asked for by Col. Johnson would not interfere with the provision of cyclist battalions, there could not possibly be any objection to them; his own experience was that twenty cyclist companies would never be equal to one well trained cyclist battalion. In practice a cyclist company would often consist only of cycle orderlies who would run about between companies of the regiment, and, who would, probably, on service; be taken away to form a scratch battalion.

\section{Separation Allowances.}

With regard to separation allowances, they were very. important in Wales., Men would stop their fifteen days in camp if they could get sufficient money to keep their homes together. In the industrial centres 
of Wales they did not pay the collier when he was in camp. If a bounty was to be given, they wished to participate in it, but only if it was paid at the time when it would be useful to the men. Any bounty, to be useful, must be given at the end of the first week, on the guarantee that the man would stay on for the fifteen days. He could then remit the money home to keep his wife and family. His Association was much in favour of married men. An unmarried man in the mining districts sometimes got into some trouble and went off under a false name to some other district, and they lost his equipment, his rifle, etc. But a married man, as had just been said, was localized, and was more valuable than the single.man.

Captain F. Colchester Wemyss (Gloucestershire Association) said that as coming from a county which had raised roo per cent. of its establishment he might be pardoned for being optimistic. But whether they were altogether optimistic about the Territorial scheme or not, he thought everyone would agree that it was at any rate immeasurably superior to the old Volunteer system.

The last speaker had said that he was afraid the Voluntary Aid Detachments in the counties would interfere with recruiting for the Territorial Force. In Gloucestershire they had not found that was the case. In Gloucestershire and in Bristol they had not only 100 per cent. of their establishment, but, he believed, they had the largest number of Voluntary Aid Detachments. They were a very important part of our present organization, because on them depended to a great extent, the keeping clear of the lines of communication in times of war.

But though a great improvement on its predecessor, the Territorial scheme was, of course, by no means perfect. There was undoubtedly a great feeling of irritation among the Territorial Associations and the members of units throughout the country against the War Office. They could not help feeling they were not being treated sympathetically or in a businesslike manner when letters took ten or twelve weeks to receive an answer. There was no reason why an answer should not be obtained as quickly from the War Office as from any large business house.

Secondly, with regard to finance, he believed that now the grants had been raised they had quite enough money for administrative purposes. But he thought everyone would agree that Associations ought to have a much freer hand than they had. For instance, in Gloucestershire during the past year they felt, and all the military authorities had pressed it on them, that the artillery ought to have a nucleus of trained horses with which to practice. They had arranged to borrow the money required for this purpose at $2 \frac{1}{2}$ per cent. from the Bank. All they asked was the sanction of the War Office, but this was refused on the ground that their reserve fund was not large enough. This showed that they ought to have more elasticity with regard to money.

\section{Differentiation in favour of Territorials.}

Another most important point was the necessity for differentiating between the Territorial soldier and the rest of the civil population. There was no differentiation now except that the Territorial was rather worse off. There were many ways in which this might be done. Separation allow: ances were, he thought, most important; they ought to get a small amount of pay for doing drills just as when in camp; then there might be a remission of rates made to.Territorial soldiers, to the extent of $£_{2}$ or $£_{3}$, 
or $\mathcal{E}_{4}$. At any rate in some manner or other a differentiation ought to be made. At present the Territorial soldier often said he could not afford to carry on with this Territorial scheme; but they wanted to make the service so attractive to him that he would say he could not afford to leave the Territorial Force.

The Chairman: I am sorry to say I have to leave now to keep an appointment at 6 o'clock, and I am therefore going to ask your permission to say a very few words and then to vacate the Chair in favour of Sir T. S. Cave, a member of the Council.

\section{Recruiting.}

1 think it is clear that we shall all be agreed there are certain classes on whom, in regard to recruiting, the Territorial Force makes little impression. Except in the Yeomanry and the Cyclists, and perhaps some other fortunate corps, we do not recruit freely from the lower middle class, from the small shopkeepers, or from the higher class of artisans; and we are opposed, as General Bethune mentioned, by foremen in big works on account of their holidays and those of the Territorials clashing. Then in agricultural counties like my ow'n we have found that it is very difficult to tap the small parishes. In Devonshire we have $25^{\circ}$ parishes with populations of less than 500 . A population so small as that can hardly support a detachment, and any men enlisting have almost invariably to go elsewhere for their drills. That really puts out of court a population of something over 60,000 in our county as a recruiting ground, and even the parishes which are slightly larger in population, unless they lie convenient to others, are also difficult- recruiting grounds. That drawback, which must exist in every county in England, I think people do not sufficiently allow for when they compare the number of recruits raised in any county with the gross population of the county. The concessions which have been made with regard to travelling allowances will certainly go some way towards diminishing the difficulties under which people labour in regard to getting recruits from the outlying villages; but it never can or will be easy to give to men recruited in such places the instruction which they ought to receive before they go into camp. With regard to the men of the superior class, whom we do not get now; I think that the grant of a separation allowance, if it materializes, as there is some reason to belicve it may, will bring in some of them; but what I believe would be of more importance in connection with that would be for the military authorities to take rather more pains to make men comfortable in camp. I know of a case which occurred last year, where the latrines in the brigade camp were very much the reverse of what they should be, and for the sake of a few pounds it is really not worth while to disgust men with the sanitation of the camps. Another point which is of inportance from the recruiting point of view is the provision of dining tents for every battalion, so that the men shall not have to mess in their bell tents. Some battalions have funds with which they arrange to have these things, but it is not quite fair to put. it entirely on the private funds of units, and 1 think it would be money well laid out, both from the recruiting point of view and from the point of view of getting a better class of men, to spend a little more in making the men reasonably comfortable in the camps. They would be quite ready to rough it if really necessary, but they do not care to live like pigs when there is no real necessity for it. 


\section{The. Silence of Caininet Ministers.}

Then there is no doubt we have a heavy deadweight of discouragement to fight against. Colonel Johnson alluded to one feature, the silence of Lord Haldane's colleagues in regard to the Territorial Force. Cabinet Ministers and members of the Government have made, I suppose, hundreds of speeches since the Territorial Force was started, and Lord Haldane himself has worked like a slave at it, but I can only recall two speeches made by colleagues of his of any importance in which they had a good word to say for what their own colleague was doing. Not only that, but the attitude taken up by some of them has been very detrimental to the efforts which are necessary to make a success of a national movement of this sort. Of course, it is well linown that the Territorial Force is run to a very large extent by gentlemen who in politics are not in sympathy with the present Government. Nobody has acknowledged that more generously than Lord Haldane himself. I know I am going to slate on rather thin ice, but I am going to say that from my own personal experience I know there are people who, when they are asked to help in matters connected with the Territorial Force say, "Why should I put myself out of the way, to help this infernal Government? The Income Tax is is. $8 \mathrm{~d}$., and my son will have to pay 25 per cent. in death duties. This country is ceasing to be a place for any gentleman to live in-it is going to blazes. Let the blessed Government defend it themselves." I. have not the slightest sympathy with that attitude myself; $I$ think it is a most reprehensible one; but still it exists, and speeches similar to those which were delivered at Limehouse on a certain occasion are very largely responsible for it.: I do not care who knows it or who knows that I said it, because. I think that responsible people ought to know that this feeling exists.

\section{Tile NeEd, for More Elasticity.}

In regard to recruiting generally, I entirely agree with those gentlemen who said that the best recruiters after all are the officers and non-commissioned officers of the corps. In that connection I think it is important to give greater facilities for the instruction of both officers and men. I do not believe that there is enough elasticity at present in the schools for one or the other. Any Government Department I have ever had anything to do with has been generally run on the assumption that every town is like Loridon, and every county like Lancashire. It does not seem to enter into their ideas that a certain number of their fellow creatures may reside in places like Ross and Cromarty, alluded to by Colonel Ross, and that everybody does not live with a tramway at his door and within three minutes of a Tube or Railway Station. I think a great deal might be done by having more elasticity about the arrangements for schools, both for officers and for non-commissioned officers, and if the money laid out on them was allowed to be spent to some extent by brigadiers and by commanding officers in schools, run rather on the go-as-you-please principle, men coming when they can, not necessarily for a month on end, but putting in three days in one week, and five days next week, or coming in the eveningsgetting the instruction as they can and when they can, provided only they get the instruction, it would be a good thing. That was the principle, I belicve, adopted by Colonel Hutton, when organizing the Commonwealth Force in Australia, and he found it answer remarkably well, and I think it would be applicable to a great many instances in this country.

Further, in the case of these schools, I think the principle of paying 
army rates of pay should be abandoned. If you are going to pay pcople at all for coming to the schools you must remember that perhaps the subaltern or the lance corporal in a Territorial Battalion is a man who is earning about as much in private life as the sergeant-major or the commanding officer, and for the men, at any rate, I think it would be very much better to give an average pay all round, something like $3^{5}$. or 3 s. $6 \mathrm{~d}$. a day, which would represent their civilian earnings, rather than to graduate it too nicely in accordance with the scale of pay in the Regular Army. I must say I was very glad to hear the opinion expressed by various speakers that the money on the whole was fairly, sufficient, That, certainly; is the result of my own experience, and I think if commanding officers knew the regulations and claimed all they could under those regulations, they would find in many respects, especially with regard to travelling grants; that they were very much better off than they think they are; and they could really get pretty well enough to do justice to the men under their command.

Major S. H. Godman, D.S.0. (Secretary Middlesex County Association) said that Colonel Johnson had described as the three great evils of the present time the extraordinary pessimism of the press, the extraordinary optimisni of the Secretary of State for War, and the extraordinary silence of members of the Cabinet. He did not think there was much that need be said about the first two, but the silence of the Cabinet had done an immense amount of harm to the Territorial Force. If they did not approve of Lord Haldane's scheme, he could not see by what right they accepted it on behalf of the country. If they did approve of it he could not see why they should have refrained from supporting its promoter. Although they had always got Lord Haldane to help them whenever they had anything to put forward; when it came to their turn to lend him a hand scarcely one of them had so much as raised a finger. That this attitude of utter indifference to home defence really represented their true sentiments he simply could not believe, but he was quite sure that a large mass of the public had taken it in that way, and he should not be at all surprised if the present Government did not go out of power leaving the country a good deal more apathetic than they found it.

He suggested that the most pressing requirement of the Territorial Force was to bring the Government to a proper sense of its duty. $\mathrm{He}$ did not know how:it ought to be done, but he thought that these gentlemen ought to be told that if they wished the Territorial Force to be a success they had got,: whether they liked it or not; to take an active interest in that scheme for home defence, which their own party had put before the country and asked the country not only to accept but to support.

Lieut.: Colonel W. Campbell Hyslop (Secretary City of London Association) said that two points arose out of Colonel Johnson's remarks, which sounded to him like the Litany of the Territorial Force.

\section{Thie National Reserve.}

One was in connection with the National Reserve and was important. Colonit Johnson had rather suggested that the National Reserve might interfere with the recruiting of the Territorial Force, and he wanted to take this opportunity of disabusing his mind of that. In the first place, no man of the Territorial Force could enter the National Reserve until he had done eight years service in the Territorial Force. In the second 
place, the men who were in the National Reserve were 75 per cent. regulars; and they had never joined the Territorial Force or the Volunteers in any considerable number and therefore might be disregarded. Then over 25 per cent. are ex-Volunteers and perhaps veterans, and they did not want them, so he thought it was quite clear that the National Reserve did not interfere with recruiting for the Territorial Force. If the proposal. that had been made to the War Office came off, that the National Reserve shouk be asked to form a special section to constitute the Territorial Force Reserve inștead of the present Territorial Force Reserve which had not filled, then it was very much to their interest to see that good men did join the National Reserve. They would form the real reserve for the Territorial Force. In London they had 23,000 and they found the National Reserve was one of the finest educational mediums in the country. They uere mostly well-todo respectable men and they gave a very high impression of the Army and taught people about the Empire. They believed them to be the finest recruiting medium that it was possible to get. Every old soldier in the National Reserve was a potential recruiting sergeant. To their surprise they had found that the numbers of Territorials in. London were increasing within the last three months, and the only thing they could attribute it to was the development of the National Reserve, because it was a most unusual condition to get increased numbers of the Territorials at this time of the year.

\section{Tile Territorials and tile Insurance Act.}

He held in his hand a copy of the Insurance Act, and he wished to give them some idea of the possibilities of the National Insurance Act in relation to the Territorial Force. It was true that the Government missed an opportunity of doing a great deal of good by putting the Territorial soldier on the same footing as the Regular soldier, but apart from that he wished to suggest to this meeting and to the County Associations whether it would not be possible to make the Territorial Force as a whole into an approved society under the Insurance Act. If so there were great possibilities. It might be possible, as the Territorials were really picked lives, to get a reduced insurance, if not a free insurance for the men. If they could get it reduced to such an extent as to mitigate the $2 \frac{1}{2}$ per cent. charge upon the wages bill of the manufacturers-and that was what they said would be the charge under the Insurance Act-and if they could get the men all to join an approved Society consisting of the whole. Territorial Force, and the men were compelled to come to headquarters once a week to have a stamp affixed or a mark put to their book, they would at once get a grip on the Territorial Force which up to now had been only a dream. He suggested that the Central Council might very well be asked to go carefully into this question and consider the possibilities of the Insurance Act in connection with the Territorial Force. An approved Society had to conform to three things. First of all it must not be a Society carried on for profit. The Territorial Force certainly was not. Secondly, honorary members had no right to vote; and thirdly its constitution must provide for the members having absolute control, including the election and removal of the Committee of Management or the delegates of the Society; It was a matter. Which he did not profess to do more than indicate to them as being worthy of the consideration of those interested in the Territorial Force. 
Colonel W. Mellis (County of Aberdeen Association) said that he wished to say one or two words in connection with recruiting. He had hoped to have heard more definite proposals for getting the recruits to fill up the numbers deficient in the Force. In Aberdeenshire, where they had a very scattered population and few large towns, they had a very complete system of recruiting. Very early in its life the $A$ ssociation found that the real recruiters were the C.Os., the officers, and men, of the units, and that all the Association could do was to give them all possible encouragement in the matter of funds and help them in every way to recruit in the County. In every unit in the County they had a Central Recruiting Committee, and in every company they had a Recruiting Committee. That method had worked very well, and for some time recruiting had been carried on in a systematic and thorough manner.

The Need of Greater Inducements.

Before the adoption of the Territorial Force Aberdeenshire had a larger number of Volunteers than it had now, and there ought to be no difficulty, if they were properly treated, in being able to raise their full quota of men. But what was the position now? IVith all their thorough recruiting they could only raise 80 per cent., and for his part he could see no prospect of raising any more. His Association had come to the conclusion that the inducements offered to the men joining the Territorial Force were not sufficient to touch a very large class of men. They had done all they could to make the men comfortable in camp; they had had drill halls built for them, but still they found they had reached high water mark in the way of recruiting, and they were strongly of opinion that something should be done, either in the shape of payment for attending drill, compensating the man for his loss of time, or a bounty to the man who made himself efficient. If something of that sort were done it would have a very good effect. They were beginning a new season and if anything like this was to be done it should be done at once.

The Chairman: That, Gentlemen, concludes our meeting, and I think you will agree with me we have had a very useful one, and I hope the report of the proceedings will do much good.

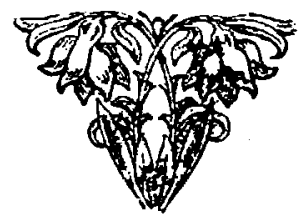


THE DIVISION OF PARTIES AT END OF DECEMBER, $19 \mathrm{r}$. (Redrawn from the Temps.)

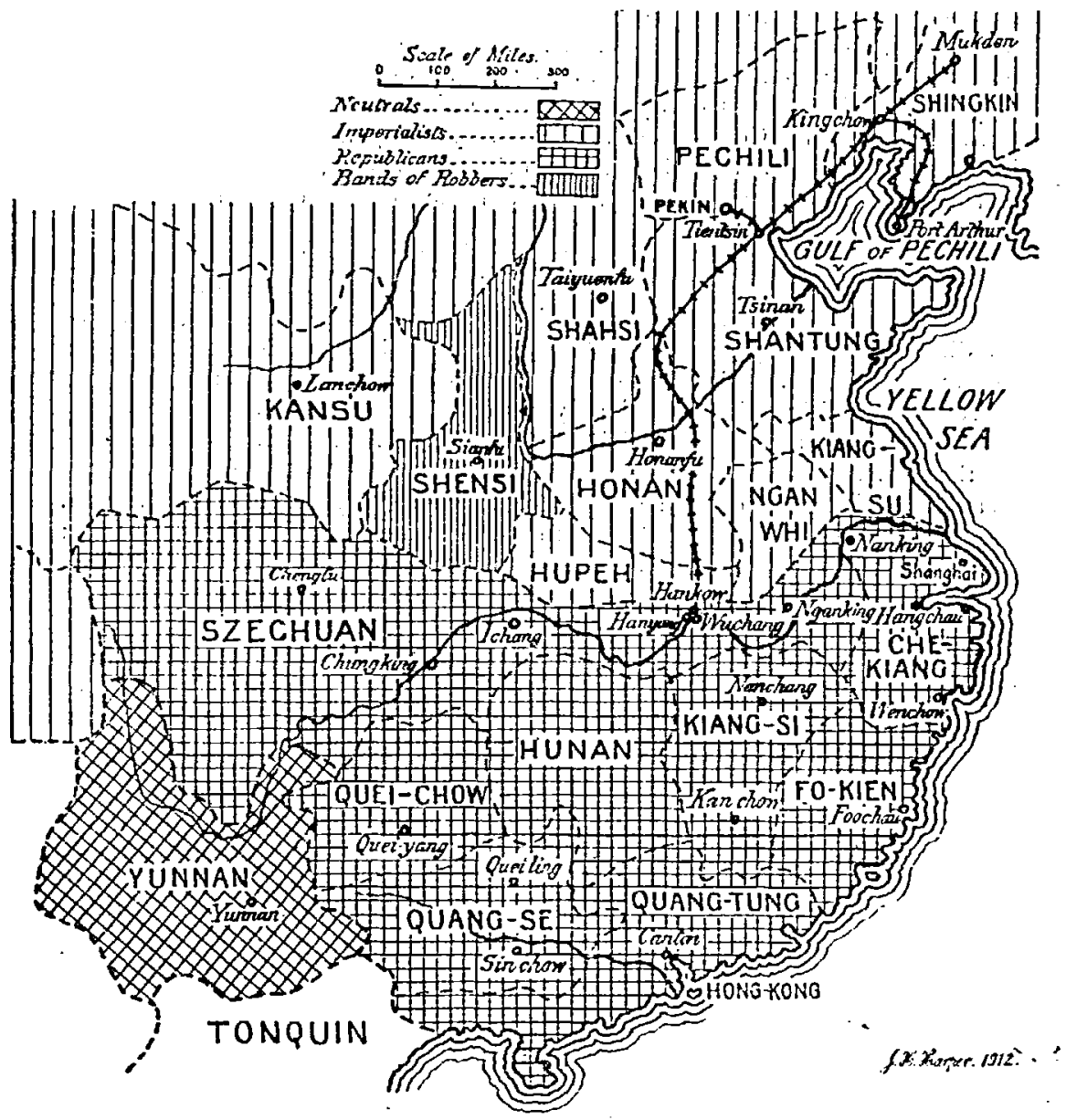

Norz.-The above map shows approximately the division of parties at the beginning of rgra. The situation has, however, developed rapidly during the last few days of January and it would appear that Shensi, Ssu-ch'uan and Kuei-Chou are almost entirely in the hands of brigands; Yun-nan, which contains ${ }_{2}$ to 13 million inhabitants, may by now be considered as revolutionary, while Tibet can scarcely any longer be reckoned as Imperialist. 